\title{
Rubber band ligation and infrared photocoagulation for the outpatient treatment of hemorrhoidal disease ${ }^{1}$
}

\section{Ligadura elástica e fotocoagulação com radiação infravermelha no tratamento ambulatorial da doença hemorroidária.}

\author{
Maurício Pichler Ricci I , Délcio Matos ${ }^{\text {II }}$, Sarhan Sydney Saad ${ }^{\mathrm{III}}$ \\ I Post-Graduate student, Surgical Gastroenterology UNIFESP, Brazil. \\ II Full Professor, Division of Surgical Gastroenterology, Department of Surgery, UNIFESP, Brazil. \\ III Associate Professor, Surgeon-in-Chief of Coloproctology, Division of Surgical Gastroenterology, Department of Surgery, UNIFESP, \\ Brazil.
}

\begin{abstract}
Purpose: To compare the results of rubber band ligation and infrared photocoagulation for the treatment of hemorrhoidal disease through the analysis of the incidence of complications after each treatment and respective success rate. Methods: Forty-eight patients with first, second or third degree hemorrhoidal disease were randomized to recieve treatment with either rubber band ligation ( $\mathrm{n}=23$ ) or infrared photocoagulation $(\mathrm{n}=25)$. Each patient was assessed at 1 week and 4 week intervals after treatment. We compared the incidence of complications and efficiency of each treatment modality and Qui-square, Fisher's Exact Test and Student's t Test were used to statistical analysis. Results: Bleeding occured in eigth $(34,7 \%)$ patients treated with rubber band ligation and in four (16,0\%) after infrared photocoagulation $(\mathrm{p}=0,243)$. Thirteen $(52,0 \%)$ patients felt pain during infrared photocoagulation and $9(39,1 \%)$ after rubber band ligation $(\mathrm{p}=0,546)$. After rubber band ligation, $14(60,8 \%)$ required medication for pain relief. One patient $(4,0 \%)$ required medication after infrared photocoagulation $(\mathrm{p}<0,001)$. Three $(13,0 \%)$ patients treated with rubber band ligator and $1(4,0 \%)$ treated with infrared photocoagulation had symptomatic mucosal ulcers. Perianal dermatitis occured in two $(8,0 \%)$ patients treated with infrared photocoagulation and one patient $(4,3 \%)$ was observed to have prolapsed thrombosed piles after rubber band ligation. One month after treatment, 17 of 23 patients treated with rubber band ligation $(73,9 \%)$ and 18 of 25 patients treated with infrared photocoagulation were asymptomatic. Rubber band ligation treated bleeding and prolapse in $90,0 \%$ and $82,4 \%$ respectively. Infrared photocoagulation treates bleeding and prolapse in $93,7 \%$ and $87,5 \%$ respectively. Those differences are not significant. Conclusion: Rubber band ligation causes significantly more pain than infrared photocoagulation during the first week after the procedures and their success rate are not different after four weeks of treatment.
\end{abstract}

Key words: Hemorrhoids. Ligation. Randomized controlled trials.

\section{RESUMO}

Objetivo: Comparar os resultados da ligadura elástica com os da fotocoagulação com radiação infravermelha no tratamento da doença hemorroidária através da análise de suas respectivas morbidades e eficácia. Métodos: Foi realizado ensaio clínico casualisado com 48 pacientes portadores de doença hemorroidária graus I, II e III. Após randomização, os pacientes foram submetidos à ligadura elástica $(n=23)$ ou fotocoagulação com radiação infravermelha $(n=25)$. Os pacientes compareceram para consulta ambulatorial 1 semana e 4 semanas após o procedimento. A avaliação foi feita através da análise da incidência de morbidades após cada procedimento e eficácia, com quatro semanas de acompanhamento. As análises estatísticas foram realizadas através do teste do Qui-quadrado, Teste Exato de Fisher e Teste $t$ de Student. Resultados: Dos pacientes submetidos à ligadura elástica, 34,7\% (8/23) apresentou sangramento após o procedimento. Após fotocoagulação, $16,0 \%(4 / 25)$ tiveram sangramento ( $\mathrm{p}=0,243)$. A incidência de pacientes com dor no momento da aplicação do procedimento foi de 52,0\% (13/25) após fotocoagulação com radiação infravermelha e 39,1\% (9/23) após ligadura elástica $(\mathrm{p}=0,546)$. No entanto, ligadura elástica foi mais dolorosa após 48 horas do procedimento $(\mathrm{p}=0,044)$. Após ligadura elástica, $60,8 \%$ $(14 / 23)$ dos pacientes necessitaram de analgésicos contra 4,0\% $(1 / 25)$ após fotocoagulação com radiação infravermelha $(p<0,001)$. Um paciente submetido à ligadura elástica $(4,3 \%)$ evoluiu com trombose dos mamilos ligados. Três pacientes submetidos à ligadura elástica $(13,0 \%)$ e $1(4,0 \%)$ submetido à fotocoagulação com radiação infravermelha apresentaram úlceras sintomáticas após a aplicação dos tratamentos. Dois pacientes $(8,0 \%)$ submetidos à fotocoagulação com radiação infravermelha tiveram dermatite perianal. Em relação aos resultados terapêuticos $73,9 \%$ dos pacientes submetidos à ligadura elástica e $72,0 \%$ daqueles tratados com fotocoagulação com radiação infravermelha estavam assintomáticos após 1 mês de tratamento. A ligadura elástica foi eficaz no controle do sangramento de $90,0 \%$ dos pacientes e a fotocoagulação com radiação infravermelha foi eficaz no controle do sangramento em $93,7 \%$. No controle do prolapso, a ligadura elástica foi eficaz em $82,4 \%$ dos pacientes e a fotocoagulação com radiação infravermelha em $87,5 \%$. Diferenças não significantes. Conclusão: A ligadura elástica causa significantemente mais dor que a fotocoagulação com radiação infravermelha na primeira semana após a aplicação dos procedimentos e a eficácia dos métodos são semelhantes após quatro semanas de tratamento. Descritores: Hemorróidas/terapia. Ligadura. Fotocoagulação.Ensaio controlado aleatório.

1. Study performed at Division of Surgical Gastroenterological, Department of Surgery, Federal University of São Paulo (UNIFESP), Brazil. 


\section{Introduction}

The majority of patients suffering from hemorrhoidal disease may be treated with conservative therapy as outpatient procedures. Two meta-analysis $(1,2)$ have shown that rubber band ligation (RBL) and infrared photocoagulation (IRCP) are the treatment of choice for first, second and third degree symptomatic hemorrhoids. However, the superiority of one modality over another is not a consensus. We therefore conducted a prospective and randomized clinical trial to compare infrared photocoagulation with rubber band ligation for the office treatment of hemorrhoidal disease.

\section{Methods}

Fifty-five consecutive patients with prolapsing or bleeding hemorrhoids reffered to our outpatient department at São Paulo Hospital/ Paulista School of Medicine (UNIFESP) were included in the study. After interview and proctosigmoidoscopy the patients were randomly allocated to treatment by either rubber band ligation or infrared photocoagulation. Patients with coagulation disturbance, immunosuppression or any other coloproctological disease were excluded. Rubber band ligation was performed using a McGivney band ligator, following the techniques described by Barron (3). One or two hemorrhoidal bundles were banded at a time. We used the Redfield Infrared Coagulator (Redfield Corporation, New Jersey, USA). The tip of the light guide of the coagulator is positioned in the mucosa immediately proximal to the hemorrhoidal bundle, high above the dentated line. A timer sets the light pulse to 1,25 seconds. Three or four sites were coagulated for each orrhoid and three bundles were treated at a time. Both procedures were done in a knee-chest position. We recorded the presence of pain during the procedure. We advised all patients regarding the intake of fibers and fluids and prescribed Psyllium when needed. The patients were oriented to take Sodium Diclofenac 50mg in case of pain. The patients were assessed at one-week and four-weeks intervals after treatment. At each visit an interview and a proctoscopy were undertaken. We compared the incidence of complications, the number of patients who took analgesics, and the efficiency of each treatment modality.

Four patients in the infrared photocoagulation group and three in the rubber band group were submmited to another session of treatment because of residual symptoms. We analysed the results one week and four weeks after the second session of treatment. No patient was submitted to more than two sessions.

The Qui-square, Fisher's Exact Test and

Student's t Test were used to statistical analysis.

This trial was approved by the Ethical Committee on Human Experimentation of the Escola Paulista de Medicina/UNIFESP.

\section{Results}

Seven patients were lost to follow-up leaving 48 patients to analysis. Twenty-five patients were treated by infrared photocoagulation (group 1) and 23 were treated by rubber band ligation (group 2). There were no statistically significant differences between treatment groups in terms of age, sex, hemorrhoidal degree and bleeding (Table 1).

Table 1 - Comparison between the two groups

prolapse prolapse

\begin{tabular}{llllllll}
\hline \multicolumn{1}{l}{ Male } & Female & Mean age & First degree & Second degree & Third degree & Bleeding \\
\hline FRIV & $14(56,0 \%)$ & $11(44,0 \%)$ & 53,4 & $8(32,0 \%)$ & $16(64,0 \%)$ & $1(4,0 \%)$ & $20(80,0 \%)$ \\
LE $11(47,8 \%)$ & $12(52,2 \%)$ & 55,2 & $4(17,4 \%)$ & $14(60,9 \%)$ & $5(21,7 \%)$ & $16(69,6 \%)$ \\
\hline
\end{tabular}

There were no severe complications nor fever, urinary retention or intense perianal pain. Those symptoms are suggestive of perineal sepsis, a rare, serious and potentialy fatal complication of rubber band ligation.

Thirteen $(52,0 \%)$ patients felt pain during infrared photocoagulation and $9(39,1 \%)$ patients felt pain during rubber band ligation. This difference is not significant $(\mathrm{p}=0,546)$. In group 1 , one $(4,0 \%)$ patient took analgesics and in group 2, $14(60,9 \%)$ patients took analgesics. This difference is statistically significant $(p<0,01)$. Another significant difference were obtained in the number of patients who took analgesics for more than 48 hours, 6 in rubber band group and 1 in infrared photocoagulation group $(\mathrm{p}=0,04)$ (Figure 1). 


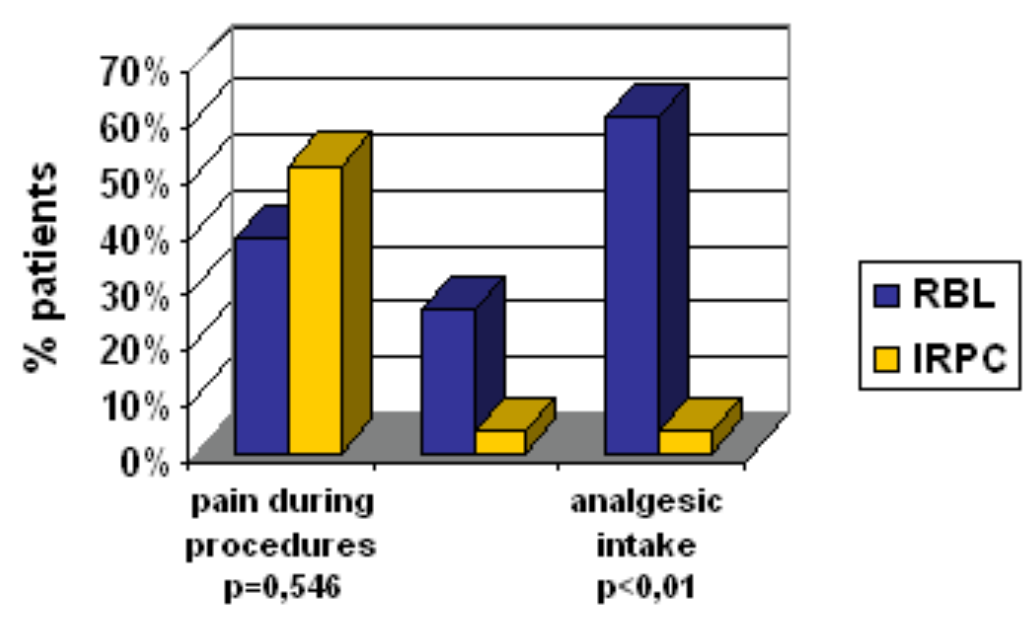

FIGURE 1 - Pain during and after procedures (percentages)

One week after the procedure, four patients $(16,0 \%)$ in group 1 and 8 patients $(34,8 \%)$ in group 2 reported bleeding. This difference is not significant $(p=0,243)$.

Painful mucosal ulcers occured in one patient $(4,0 \%)$ in group 1 and in three patients $(13,0 \%)$ in group 2 . This difference is not significant $(\mathrm{p}=0,338)$.
In group 1, two patients had perianal dermatitis treated conservatively and in group 2, one patient developed thrombosis in the banded hemorrhoids. He was submmited to hemorrhoidectomy with good results. The overall incidence of complications are depicted in Figure 2.

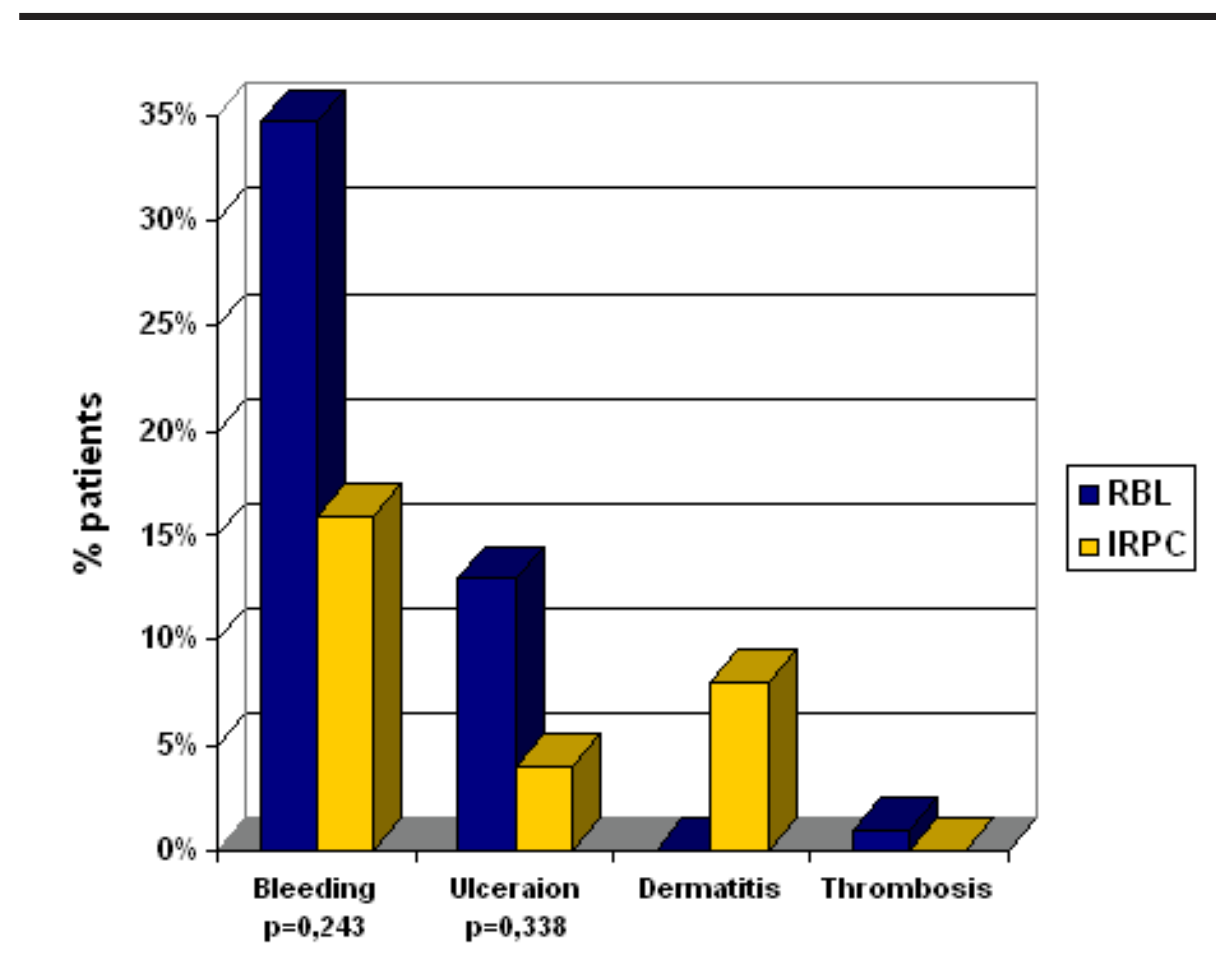

Figure 2 - Incidence of complications (percentages) 
Four weeks after treatment, $18(72 \%)$ patients were assymptomatic in group 1 and $17(73,9 \%)$ were assymptomatic in group 2 . This difference is not significant $(p=0,860)$ (Figure 3$)$.

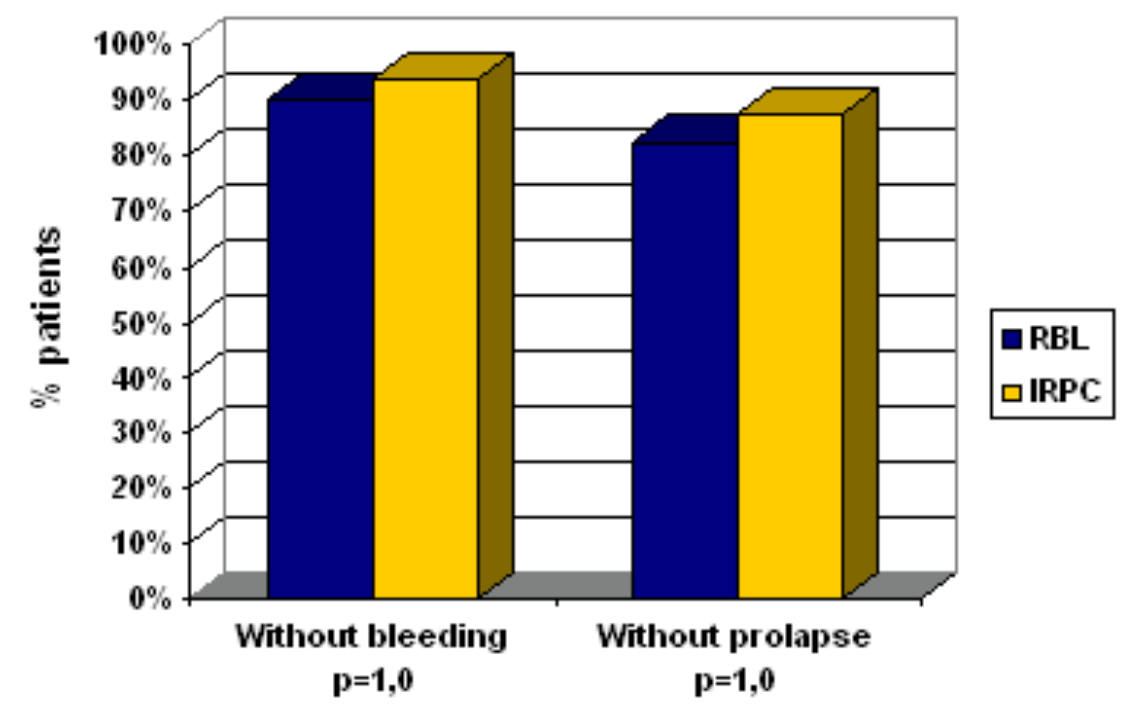

FIGURE 3 - Patients without bleeding and prolapse after procedures (percentages

Fifteen $(93,7 \%)$ patients in group 1 were free of bleeding versus $18(90,0 \%)$ in group 2 , difference not significant $(p=1,00)$. In group $1,14(87,5 \%)$ patients were free of prolapse versus $14(82,4 \%)$ in group 2 , difference not significant $(p=1,00)$. These percentages are related to the patients who had prolapse and bleeding before the procedures (Figure 4).

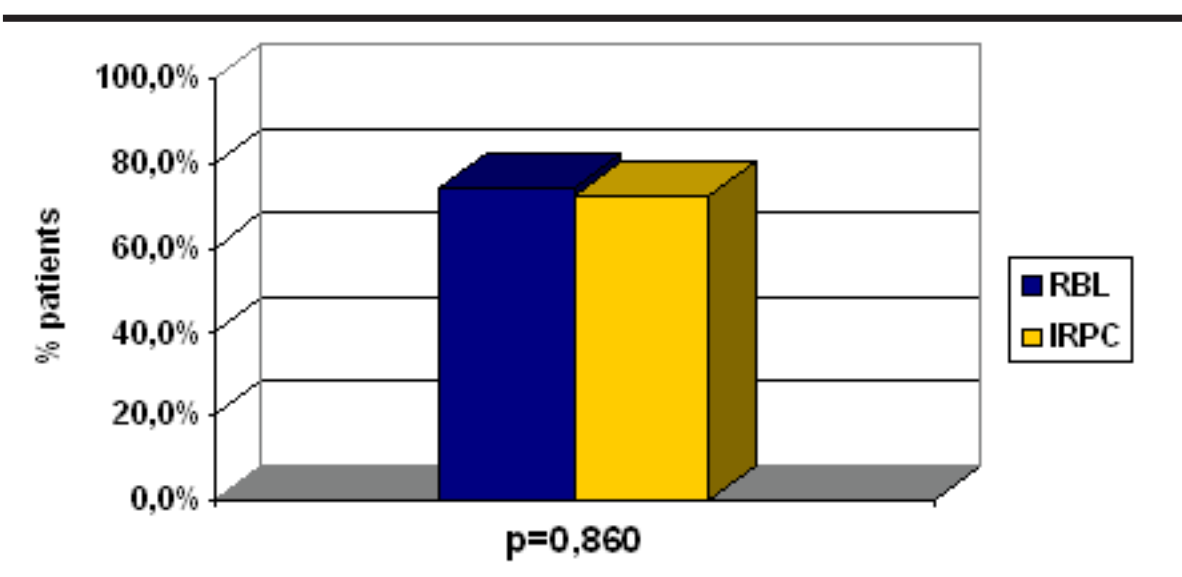

FIGURE 4 - Asymptomatic patients one month after both procedures (percentages)

\section{Discussion}

Since it's introduction by Barron (3) in 1963, rubber band ligation for the treatment of first, second and third degree hemorrhoids has been widely accepted. In Germany, Nath and Neiger $(4,5)$ developed the infrared photocoagulator. It was tested with succes for the treatment of hemorrhoids.

Two meta-analysis were published. Johanson, in 1992 concluded that infrared photocoagulation is the optimal nonoperative hemorrhoidal treatment and in 1995, Mac Rae concluded that rubber band ligation should be the treatment of choice for first, second and third degree hemorrhoids. Therefore, we still need scientifical evidences regarding those forms of treatment in our path to a consensus.

Previous publications have shown that rubber band ligation causes more pain than infrared photocoagulation (6-10). Our work has similar results regarding pain. The rubber band ligation causes significantly more pain than infrared photocoagulation during the first week after the procedure.

The incidence of minor bleeding after the procedure ranges between 0 and $37,0 \%$ for rubber band ligation $(3,11$, $12,13)$ and 0 and $49,2 \%$ for infrared photocoagulation, ( 13 , 
14, 15) without statistical differences. Our results are similar. Major bleeding after both procedures is rare.

We didn't find a report of perianal dermatitis nor mucosal ulcers after infrared photocoagulation and rubber band ligation.

The reasons for the occurence of perianal dermatitis in two patients after infrared photocoagulation are unclear. Increased anal discharge may be the cause of dermatitis in one of these patients and the use of ointment in the other one.

Overlaping two shots is the probable cause of painful ulcer after infrared photocoagulation. In the case of rubber band ligation, the amount of destructed tissue is less predictable and major ulcerations may happen.

The incidence of thrombosis after rubber band ligation is low and we had one patient with this complication. He was submitted to hemorrhoidectomy with good results.

Despite the fact that our follow-up is very short, we found that our success rate was good and similar between the two groups. Figure 2 shows the overall incidence of complications.

\section{Conclusion}

Rubber band ligation causes more pain than infrared photocoagulation and their short term clinical results are similar.

\section{References}

1. Johanson JF, Rimm A. Optimal nonsurgical treatment of hemorrhoids: a comparative analysis of infrared coagulation, rubber bandligation, and injection sclerotherapy. Am J Gastroenterol 1992;87:1601-6.

2. MacRae HM, McLeod RS. Comparison of hemorrhoidal treatment modalities: a meta-analysis. Dis Colon Rectum 1995;38:687-94.

3. Barron J. Office ligation of internal hemorrhoids. Am J Surg 1963; 105:563-70.

4. Nath G. The new principal of infrared coagulation in medicine and its physical fundamentals. Colo-proctology 1981;3:379-81.

5. Neiger A. Infrared-photo-coagulation for hemorrhoids treatment. Int Surg 1989;74:142-3.
6. Leicester RJ, Nicholls RJ, Chir M, Mann CV. Infrared coagulation: a new treatment for hemorrhoids. Dis Colon Rectum 1981;24: 602-605.

7. Marques CFS. Resultados imediatos do tratamento da doença hemorroidária interna pela fotocoagulação por radiação infravermelha e ligadura elástica: estudo prospectivo e randômico. [Tese - Mestrado]. São Paulo: Faculdade de Medicina da Universidade de São Paulo; 2001.

8. Poen AC, Felt-Bersma RJF, Cuesta MA, Devillé W, Meuwissen SGM. A randomized controlled trial of rubber band ligation versus infra-red photocoagulation in the treatment of internal haemorrhoids. Eur J Gastroenterol Hepatol 2000;12:535-9.

9. Templeton JL, Spence RAJ, Kennedy TL, Parks TG, Mackenzie G, Hanna WA. Comparison of infrared coagulation and rubber band ligation for first and second degree haemorrhoids: a randomised prospective clinical trial. Br Med J 1983;286:1387-9.

10. Walker AJ, Leicester RJ, Nicholls RJ, Mann CV. A prospective study of infrared coagulation, injection and rubber band ligation in the teatment of haemorrhoids. Int J Colorectal Dis 1990;5: 113-6.

11. Jeffery PJ, Ritchie SM, Miller W, Hawley PR. The treatment of haemorrhoids by rubber band ligation at $\mathrm{St}$ Mark's Hospital. Postgrad Med J 1980;56:847-9.

12. Bat L, Melzer E, Koler M, Dreznick Z, Shemesh E. Complications of rubber band ligation of symptomatic internal hemorrhoids. Dis Colon Rectum 1993;36: 287-90.

13. Santiago EL, Parra MG, Olivares FJM, Bautista FJP, Gutiérrez JMH. Eficacia del tratamiento hemorroidal mediante la ligadura com bandas elásticas y la fotocoagulación infrarroja. Rev Esp Enferm Dig 2001;93:238-42.

14. Zinberg SS, Stern DH, Furman DS, Wittles JM. A personal experience in comparing three nonoperative techniques for treating internal hemorrhoids. Am J Gastroenterol 1989;84:488-92.

15. Ambrose NS, Morris D, Alexander-Williams J, Keighley MRB. A randomized trial of photocoagulation or injection sclerotherapy for the treatment of first- and second-degree hemorrhoids. Dis Colon Rectum 1985; 28: 238-40.

\section{Correspondence:}

Delcio Matos

Rua Edison, 278/61

04618-031 São Paulo-SP, Brazil

Phone: (55 11) 5542-9125

dmatos.dcir@epm.br
Conflict of interest: none Financial source:none

Received: September 11, 2007

Review: November 12, 2007

Accepted: December 4, 2007

\section{How to cite this article}

Ricci MP, Matos D, Saad SS. Rubber band ligation and infrared photocoagulation for the outpatient treatment of hemorrhoidal disease. Acta Cir Bras. [serial on the Internet] 2008 Jan-Feb;23(1). Available from URL: http://www.scielo.br/acb 